\title{
Madhu Vidya: The Science and Yoga of Bliss
}

\author{
MS Srinivasan* \\ Research Associate, Sri Aurobindo Society, India
}

Submission: May 29, 2019; Published: July 10, 2019

*Corresponding author: MS Srinivasan, Degree in Electrical and Electronics engineering, Research Associate, Sri Aurobindo Society, India

\begin{abstract}
The Upanishad era in ancient India is predominantly the Age of Yoga where a community of yogis, seers and sages experimented with a multitude of methods, approaches and paths for coming into some form of inner contact with the ultimate Reality, Brahman. These experiments gave birth to many Vidyas, sciences, each Vidya trying to approach the spiritual realms through some part of our human nature or consciousness or some aspect of the divine Reality.

Keywords: Madhu Vidhya; Yogis; Consciousness; Honey; Sweetness; Joy; Sat-Chit- Ananda; Vedantic Seers; Physical; Sensational; Emotional; Mental; Spiritual; Sensational Level; aesthetic enjoyment
\end{abstract}

\section{Opinion}

We don't know exactly what the content of these Vidyas are. We can only speculate. One of them mentioned in the Upanisha dic literature was Madhu Vidya. Madhu means honey, which is a symbol of sweetness, joy. Madhu Vidya was probably an approach to the Divine Reality through Ananda or Bliss aspect of it, or in other words, the science of Yoga of bliss. This article is an attempt to arrive at a system of Madhu Vidhya based on Upanishadic teachings and other Indian conceptions.

\section{The Triune Reality}

Many great seers, sages and saints all over the world have expressed their inner experiences of the Ultimate Reality in various forms. The inner experience may be more or less the same but its outer expression in thought and concepts may differ widely according to the religious and cultural background of the mind of the experiencing soul.

Among these conceptions the most profound was the ancient Vedantic conception of the Reality as Sat-Chit-Ananda, which means, Being, Consciousness, Bliss. And the concept of Ananda, eternal Bliss, as the very nature of the Reality is something unmatched in the religious and spiritual history of the world.

According to Vedantic seers, the absolute is an infinite, eternal and timeless Sat-Chit- Ananda. It is Sat, which is usually translated as Being, but a better word would be BEness. It is the eternal Existence which give existence to all that is, or in other words, ISness of all that is. This Sat is Chit, eternal Consciousness. Chit is inherent in Sat inseparable and entirely one in identity with it. This Sat-Chit contains within itself, inseparable with it, Ananda, eternal Bliss. So, Sat which is Chit which is Ananda is the nature of the supreme reality. We are in our true self, one with these divine realities, Sat-Chit-Ananda.

\section{Ananda and Human Joys}

What is precisely this Ananda? We can know it truly only by inner experience of the Reality. In mental terms we can only give some rough indication which has to be prefixed by words like "perhaps" or probably". To begin with, we may say that Sat is the source of all existence, and Chit is the source of all consciousness and Ananda is the source of all joys in every level of our being. Whatever joys we experience at any level of our being - physical, sensational, emotional, mental or spiritual, is a more or less diminished, diluted, deformed and distorted expressions of that divine Joy, Ananda. However, this doesn't mean divine Ananda is a quantitative multiplication of human joy. The difference between human joy and divine Ananda is qualitative and dimensional and not quantitative. For example, we have the pleasures of sex and food at the lower physical and sensational level. At a higher level there is the joy of pure and selfless love at the emotional level or the joy of a deep insight into truth at the emotional or mental level, which is a qualitatively superior joy at a higher dimension. The divine Ananda of the absolute Reality is at a higher dimension than the purest and highest of human joys of our body, mind and heart.

\section{The Path to Ananda}

This divine Ananda is the consciousness of the Infinite which is free from ego and desire. This sense of the infinite and freedom from ego and desire is probably the core content of Ananda, which also gives a clue to the nature of the inner discipline we must pursue to discover Ananda, or some reflections of it in our 
mind and heart. The first, preparatory part of the discipline is renunciation of all gross pleasures of the senses like greed for food or sex. The second part is to progressively eliminate ego, desire and self-seeking from our thought, feeling and sensation. The third part is to cultivate wideness or vastness in our mind and heart. In Brihadharanyaka Upanishad the sage Sanath kumara says to his disciple, Narada "There is no happiness in Alpa, the small and the petty; there is happiness only in the Bhuma, in the vast, large and the infinite."

As we have discussed earlier, according to Vedantic teachings, our true self, which is beyond our ego, is one with the divine Reality and made of infinite being, consciousness, bliss, Sat, Chit, Ananda. Our ego is a limitation and constriction of our true Self within a narrow mould, which means limitation of being and consciousness and therefore diminution of Ananda. As we grow out of the limitations of our ego and become vaster and wider in our being and consciousness, greater the Ananda we can feel in our being and life.

However, Ananda is not only the source of all joys but also the essence of life and all human experience. Taittria Upanishad says "No one can breathe without this firmament of Ananda". This current of Ananda flows through and behind all experiences of life, pleasant, painful or neutral, good or bad as the rasa, the delightful essence or "taste" of every experience. This is the principle behind the concept of Navarasa, nine rasas of feelings, in Indian aesthetic. The Navarasas include positive emotions like love and courage and also negative feelings like fear and disgust. The main aim of the Navarasa approach in Indian aesthetics is to enter into the rasa of all experiences through an impartial aesthetic enjoyment of them through dance or literature. This is the aesthetic approach.

The other Yogic approach is through inner detachment and equanimity. The Yogi tries to inwardly detach himself from all the outer forms of experiences, pleasant or unpleasant, and tries to experience them with a calm, undisturbed equanimity. As he progresses in this discipline and touches the deepest core of the experience, he feels an equal delight in every throb of life and in all experiences. Sri Aurobindo, in one of his diary notes on his daily experiences of Yoga, wrote that he was having the experience of "Ananda of Niranada"[1] which probably means, even in a state of joylessness, behind it, there is a current of Ananda, and both these states can be experienced simultaneously.

\section{References}

1. Sri Aurobindo (1980) 'Records of Yoga' Archives and Research, Sri Aurobindo Ashram p. 65, Puducherry, India.

Your next submission with Juniper Publishers
will reach you the below assets
- Quality Editorial service
- Swift Peer Review
- Reprints availability
- E-prints Service
- Manuscript Podcast for convenient understanding
- Global attainment for your research
- Manuscript accessibility in different formats
( Pdf, E-pub, Full Text, Audio)
- Unceasing customer service
Track the below URL for one-step submission
https://juniperpublishers.com/online-submission.php

